\title{
Межэтническое взаимодействие русских и тувинцев в советской и постсоветской Туве (на примере национально-смешанных семей)
}

\author{
Зоя Ю. Доржу \\ Тувинский государственный университет, Российская Федерация
}

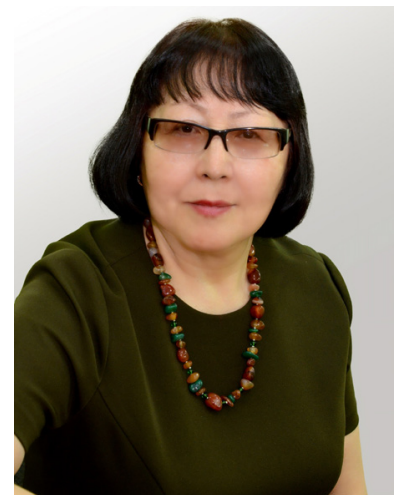

В статье анализируются проблемы межэтнических браков между тувинцами и русскими в Республике Тыва, которые рассматриваются как один из аспектов межэтнического взаимодействия двух самых многочисленных этнических групп населения. Хронологический период: советское время (1944-1991 г2.) и постсоветское (с 1991 г. по настоящее время). Источниковая база работы: статистические данные за 1979, 1989, 2002, 2007, 2010 г2.; данные опроса жителей Кызыла разных национальностей, проведенный автором в марте-апреле 2017 2.; личные наблюдения и материалы интервью 2015-2018 г2. с 20 респондентами старше 65 лет, находящимися в межнациональном браке.

Взаимодействие тувинцев и русских имеет двухвековую историю. Оно отразилось и на демографических процессах. Если раньще тувинцы предпочитали внутриэтнические брачные связи, то изменение демографической ситуации, межнациональная интеграция обусловили и появление межнациональных браков. Анализируются динамика числа браков, мотивы и факторы выбора партнера для смешанного брака, реакция окружающих, проблема детей в смешанных семьях.

Образование смешанных семей влекло за собой качественно новые черты культуры, домашнего быта, традиций, отличающих их семейный уклад от семейного быта однонациональных семей, к которым ранее принадлежали супруги. Параллельно с этим в смешанных семьях происходили языковые процессы, межэтническое общение способствовало распространению двуязычия, а также широкому распространению родственных связей, которые обеспечивали этнополитическую устойчивость многонационального региона.

В современной Туве также часто встречаются национально-смешанные семьи, однако общественное отношение к таким бракам резко изменилось. Отрицательное отношение к межнациональным бракам связано с религиозными различиями, разными традициями и обычаями. Из-за этого возникают между супругами разногласия, такие браки люди начинают расценивать как неустойчивые. Свою роль сыграло и усиление националистических тенденций в постсоветском обществе.

Ключевые слова: Тува; тувинцы; русские Тувы; демографические процессы; демография; брак; межэтнические отношения

\footnotetext{
Для цитирования:

Доржу 3. Ю. Межэтническое взаимодействие русских и тувинцев в советской и постсоветской Туве (на примере национально-смешанных семей) [Электронный ресурс] // Новые исследования Тувы. 2019, № 1. URL: https:/nit.tuva.asia/nit/article/view/835 (дата обращения: дд.мм.гг.). DOI: 10.25178/ nit.2019.1.11
}

Доржу Зоя Юрьевна - доктор исторических наук, профессор, заведующая кафедрой отечественной истории Тувинского государственного университета. Адрес: 667000, Россия, г. Кызыл, ул. Ленина, д. 5. Тел.: 8 (394) 222-18-89 Эл. адрес: zoyadorzhu@yandex.ru ORCID: 0000-0002-6409-3248

Dorzhu Zoya Yuryevna, Doctor of History, Professor and Head, Department of Russian History, Tuvan State University. Postal address: 5 Lenina St., 667000, Kyzyl, Russia. Tel.: +7 (913) 346-20-31. E-mail: zoyadorzhu@yandex.ru 


\title{
Interethnic interaction of Russian and Tuvans in Soviet and Post-Soviet Tuva: the case of ethnically mixed families
}

\author{
Zoya Yu. Dorzhu \\ Tuvan State University, Russian Federation
}

\begin{abstract}
The article analyzes issues of interethnic marriages between Tuvans and Russians in the Republic of Tuva, which are considered as one of the aspects of interethnic contact between the two largest ethnic groups in the region. The chronological frames of the study are the Soviet (1944-1991) and post-Soviet (since 1991) periods. For its sources, the study looks at statistical data for the years 1979, 1989, 2002, 2007 and 2010, also focusing on data from a survey of Kyzyl residents of different ethnic backgrounds, done by the author in March and April 2017. An additional source is found in personal observations and materials of interviews held in 2015-2018 with 20 respondents aged over 65 and in interethnic marriage.

The history of Tuvan - Russian interaction spans two centuries, and it has had its impact on demographic processes. While in the past Tuvans had preferred intra-ethnic marriage, it was the change in the demographic situation and interethnic integration which led to the rise of interethnic marriage. The article examines the dynamics of such marriages, spouses' motivation and reasons for choosing a partner, the reaction of their milieus, and the problem of children in ethnically mixed families.

The mixed family brought about new features in culture, home life, and traditions, which differentiated its new lifestyle from that of the single-ethnic family, where the spouses grew up. Meanwhile, processes of linguistic communication within the family led to increased bilingualism as well as to strengthening of new kinship ties which ensured the ethnopolitical stability of the multiethnic region.

While mixed families are still frequent in contemporary Tuva, the public attitude towards such marriages has changed to the opposite. Negative attitude to interethnic marriages is due to differences in religion, as well as in traditions and customs. Since these factors are likely to generate intrafamily controversies, such marriages are increasingly regarded as unstable. The strengthening of nationalist tendencies in post-Soviet society also played a big role.
\end{abstract}

Keywords: Tuva; Tuvans; Russians in Tuva; demographic processes; demography; marriage; interethnic interaction

\section{Введение}

Республика Тыва является многонациональным регионом Российской Федерации, на территории которой, по данным Всероссийской переписи 2010 г., зарегистрированы более 85 национальностей и этнических групп. Наиболее многочисленными являются две национальности - тувинцы $(82,0 \%)$ и русские $(16,3 \%)$. Другие национальности составляют $1,7 \%$ населения (Итоги ..., 2013: 8).

Взаимодействие тувинцев и русских ведет отсчет от 30-х гг. ХІХ в. (Кузьмин, 2000: 17; История Тувы, 2001: 235; Доржу, 2014: 160). В 1944 г. Тува вошла в состав СССР, что стало мощной предпосылкой для ее социально-экономического развития. На соответствующий уровень было поставлено здравоохранение и народное образование, стали активно развиваться промышленность и сельское хозяйство, началось масштабное строительство жилья, больниц, 
школ. Все это не могло не сказаться на демографических процессах. Численность жителей в республике за 1944-1990 гг. увеличилась более чем втрое, с 95,4 тыс. чел. в 1945 г. до 306,6 тыс. чел. в 1991 г. (Народное хозяйство ..., 1976: 3; Советская Тува ..., 1991: 46). И если раньше тувинцы предпочитали внутриэтнические брачные связи, то изменение демографической ситуации, межнациональная интеграция обусловили и появление тенденции к межнациональным бракам.

Межнациональная семья как социальный институт формируется под влиянием таких факторов как межнациональная интеграция и сотрудничество, демографические и миграционные процессы. Создание межнациональных браков во многом зависит от состояния межнациональных отношений в регионе, что является показателем толерантности различных наций и этнических общностей.

Исследования семейно-брачных отношений у народов Сибири, включая семейные традиции и их трансформации в Республике Тыва, уже исследовались учеными в разные периоды. В последние годы этой проблематикой занимались Г. В. Гончарова (Гончарова, 2004), М. В. Монгуш (Монгуш, 2005), 3. В. Анайбан (Анайбан, 2011), Т. М. Ойдуп и А.Ч. Кылгыдай (Ойдуп, Кылгыдай, 2012), А. Б. Базарова и Н. Ч. Дамба (Базарова, Дамба, 2015), А. В. Седен (Седен, 2018). Авторы констатировали тот факт, что межэтническое взаимодействие определяет этнические процессы и активно связано с такими сферами жизнедеятельности как политика, экономика, социальные отношения, культура. Это очевидно, по росту или спаду межнациональных браков в периоды социальной стабильности и нестабильности соответственно.

Современная ситуация изучения этой проблемы осложнена тем фактом, что в записи актов о браке графа «национальность», как раньше в советский период, не заполняется. Это не дает официальной статистики и требует привлечения иных данных.

В статье рассматривается основной круг проблем заключения межнациональных браков в Туве в советские и постсоветские годы, в том числе в динамике, рассматриваются мотивы и факторы выбора партнера для смешанного брака, реакция окружающих, проблема детей в смешанных семьях. Это необходимо для понимания особенностей смешанных браков и прогнозирования их дальнейшего развития в межнациональном регионе.

Источниковой базой работы стали: статистические данные за 1979, 1989, 2002, 2007, 2010 гг., материалы архива органа Управления ЗАГС Республики Тыва (агентство) в г. Кызыле за 1959, 1972, 1980, 1993 гг. Также приводятся данные опроса жителей Кызыла разных национальностей, проведенный автором в марте-апреле 2017 г. Опрос проводился с целью выяснения общего отношения к брачности, семье, ценностям семьи и брака, а также к межэтническим бракам, положительных сторон и основных проблем межнациональных браков и др. Было опрошено 350 чел. русских и тувинцев, из которых 60\% - женщины, 40\% - мужчины; в возрасте от 18 до 80 лет, различного социального положения (в том числе студенты, служащие, предприниматели, государственные служащие, пенсионеры). По семейному положению были выделены состоящие в браке и не состоящие в браке. Также автор опиралась на личные наблюдения и материалы интервью 2015-2018 гг. с 20 респондентами старше 65 лет, находящимися в межнациональном браке с целью выяснить состояние ситуации в межнациональных браках сейчас и в советский период.

Учитывалось, что численность населения Кызыла еще в 1989 г. превысила сельскую, и составляла тогда $54,0 \%$ от общего числа населения Тувы. В настоящее время здесь проживает более трети населения республики. Из проживающих в городе представителей разных национальностей тувинцы составляют 66,23\%, русские - 27,64\% (Итоги..., 2013: 17).

Все материалы опроса и интервью хранятся в методическом фонде кафедры отечественной истории Тувинского государственного университета, используются студентами для написания курсовых и выпускных квалификационных работ. 


\section{Межнациональные браки в советский период}

Советская власть активно проводила политику по укреплению дружбы народов многонационального государства, по выравниванию социально-экономического развития всех регионов страны. Все граждане, независимо от рас и национальностей, наделялись равными правами (Конституция ..., 1977: 17).

Добровольное вхождение Тувы в состав СССР привело также к значительным культурным преобразованиям здесь. Приезжавшие в республику специалисты пропагандировали новую культуру. В задачи культурно-просветительских учреждений советской власти входило изменение ментальности тувинцев, убеждение в правильности выбора социалистического пути развития (Доржу, 2015). Пропаганда интернационализма через средства массовой информации, образовательные учреждения и трудовые коллективы оказывало большое влияние на сближение народов, развитие межнациональных отношений, способствовало образованию национально-смешанных семей. Как писала Г. В. Гончарова, межэтническое взаимодействие рассматриваемых этнических групп связано с интенсивностью миграционных процессов, а также их долей в этнической структуре населения: чем выше миграция и чем меньше их доля в населении, тем больше образуется этнически смешанных семей (Гончарова, 2004: 76). В процессе национально-государственного строительства в 1940-1950-е годы произошли перемены в политической, хозяйственной, культурной сферах республики, произошли изменения в социальной структуре населения.

«В 1950-х годах, в Туве было очень много смешанных союзов, - вспоминает Г. Забелина, в девичестве Сарыглар, прожившая в интернациональном браке с супругом более 50 лет. Почти каждый второй брак был такой. В основном, пары складывались из тувинца-мужа и русской жены, как правило, выпускниц педагогических вузов, приехавщих в Туву по распределению. Много приезжало молодых специиалистов, они создавали семьи и оставались здесь на всю жизнь. Так решалась проблема укрепления межэтнических отношений, развивался процесс этнической адаптации и взаимного проникновения» (из интервью с нашим респондентом Г. Забелиной, 2017 г.).

В 1960-1970-е гг. символами динамично развивавшейся Тувы советского времени были комбинаты «Туваасбест» и «Тувакобальт». Это были ударные всесоюзные стройки, их строили и создавали сотни девушек и юношей самых разных национальностей и народностей, приехавших по комсомольским путевкам. Многие из них создавали семьи, вступали в межнациональные браки. Рост численности таких браков в стране трактовался как показатель развития дружественных межнациональных отношений, что, конечно, так и было. Да и сама республика, будучи полиэтничной, была заинтересована в расширении межэтнических браков и поддержании стабильности межэтнических семей. Такие семьи, в свою очередь, способствовали утверждению новых общесоветских традиций и обычаев, интернационализации культуры, быта, повседневной жизни. По материалам республиканского архива ЗАГС, также заключались браки между русскими и тувинцами. Так, в 1959 г. в г. Кызыле было заключено 522 брака, из них между русскими и тувинцами - 5, в 1972 г. заключено 646 браков, в том числе 22 были русско-тувинские, в 1980 г. соответственно 655 браков и 17 и в 1993 г. из 620 браков русскотувинские браки составили 22.

Образование смешанных семей влекло за собой появление в их быту многих качественно новых черт. Это приводило к изменению норм общения под влиянием межэтнических контактов во всех сферах общения, включая, прежде всего, родственные, соседские, да и просто дружеские контакты.

Язык общения играл не последнюю роль в процессе сближения этносов. Еще в середине 1940-х гг., с началом культурного строительства в условиях советского строя, в Туве получает развитие тувинско-русский и русско-тувинский билингвизм. На первых порах основным языком обучения в тувинских школах являлся родной язык, но так как большинство учи- 
тельских кадров были специалистами, приехавшими из Советского Союза и не владевшими тувинским языком, преподавание многих школьных предметов велось на русском языке. В последующие годы русский язык получает широкое распространение не только в школьном обучении, но и в других сферах. Многие из специалистов, попавшие по распределению своих вузов в сельскую местность, начинали говорить на родном языке местного населения. Тувинцы очень уважительно относились к приехавшим в Туву специалистам, особенно к тем, кто хотя бы на бытовом уровне понимал тувинский язык, хоть и не умел говорить на нем. В то же время сами тувинцы, помимо родного языка, хорошо стали владеть русским - языком межнационального общения и приобщения к культуре русского народа. Межэтническое общение (в том числе и смешанные браки), способствовали распространению двуязычия. Согласно статьи 5 Конституции Республики Тыва, государственными языками Республики Тыва являются тувинский и русский языки (Конституция ..., 2001: 5). Поэтому национально-русское двуязычие является объективным, социально необходимым явлением.

Основной массив городских семей в Туве в 1970-е гг. составляли русские семьи со значительно меньшим количеством человек в них (3,4 против 4,6 у тувинцев). В структуре семей городского населения Тувинской АССР русские однонациональные семьи составляли более 2/3, а тувинские только 15,5\%, как это видно из нижеприведенной таблицы.

Таблица 1. Типы городских семей по национальному составу, 1970 г.

Table 1. Urban households by ethnicity, 1970.

\begin{tabular}{|c|c|c|}
\hline Тип семьи & $\begin{array}{c}\text { уельный } \\
\text { вес, в } \%\end{array}$ & $\begin{array}{c}\text { Средняя } \\
\text { величина семьи }\end{array}$ \\
\hline Русские однонациональные семьи & 70,4 & 3,4 \\
\hline Тувинские однонациональные семьи & 15,5 & 4,6 \\
\hline $\begin{array}{c}\text { Семьи, где члены семьи принадлежат разным } \\
\text { национальностям }\end{array}$ & 12,4 & 3,7 \\
\hline Все семьи & 100 & 3,7 \\
\hline
\end{tabular}

(Рассчитано по: Итоги переписи населения ..., 1974: 326-327).

Вместе с тем, именно в городе был значителен удельный вес семей, где члены - лица разных национальностей. В зависимости от национальности колеблется и средняя величина семьи. В тувинских семьях она на 1,2 человека была больше, чем в русских. Среди тувинского населения было значительно больше семей, состоящих из 6 человек и выше (29,5\%). Среди русского населения такие семьи составляли 8,3\%. Удельный вес групп в структуре национально-смешанных семей по количеству членов семьи практически был одинаков с однонациональными русскими семьями, что свидетельствовало о более интенсивном переходе тувинцев на ценностные ориентации русских, для которых приоритетными ценностями были прежде всего: работа, хорошее образование и профессия (Гончарова, 2004: 196).

При этом брачность тувинского населения (как городского, так и сельского) у женщин была выше в младших возрастных группах (16-24 лет), у мужчин в старших (35-49 лет). У русского населения эти показатели были иные - у женщин уровень брачности был выше, чем у мужчин. Это в какой-то степени объяснялось общим превышением численности женщин русской национальности и преобладанием смешанных браков, где муж - тувинец, жена - русская (Городское население ..., 1981: 39).

В нижеприведенной таблице, составленной по данным Всесоюзной переписи населения 1979 г., представлены данные о распределении семей по их размеру и национальности. 
Таблица 2. Распределение семей по их размеру и национальности по данным переписи населения 1979 г.

Table 2. Households by size and nationality, from 1979 census data

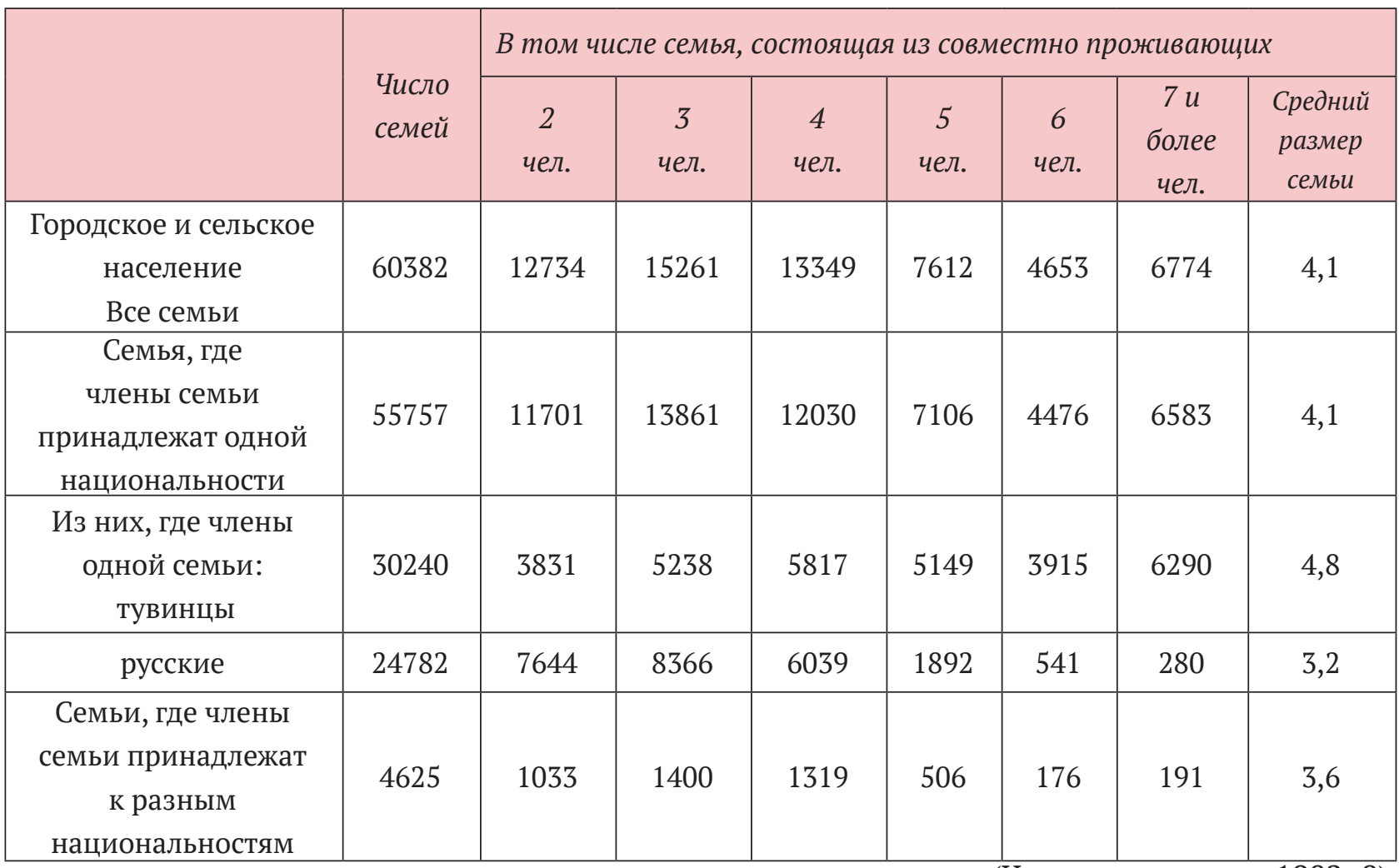

(Число и состав ..., 1982: 9).

Из таблицы видно, что перепись 1979 г. зафиксировала в республике 55,8 тысяч однонациональных семей, что составило 92,3\% от общего числа всех семей. Из них 30,2 тысячи семей $(54,1 \%)$, где все члены семьи были тувинцы, 24,8 тысячи семей $(44,5 \%)$, где все члены семьи были русские. Количество русских семей уступало численности тувинских, что определялось не только возрастной структурой тувинцев и русских, но и соотношением их в составе всего населения республики. Доля молодых возрастных групп среди тувинцев была выше, чем среди русских, отсюда была выше и доля лиц, вступающих в семейно-брачные отношения.

Среди самых многочисленных национальностей средний размер семьи в республике был больше у семей, где все члены семьи тувинцы $(4,5)$, наименьший - у семей, где все члены семьи русские $(3,2)$.

Число национально-смешанных семей составило 4,6 тысячи или 7,7\% к общему числу всех семей. Их количество было не столь значительно, но даже такая доля межэтнических браков делало их заметным общественным явлением в Туве и повышало роль в этнических процессах. Этому во многом способствовала национальная политика страны того времени, направленная на расширение межнациональных контактов, основанных на уважении и доверии, хотя на бытовом уровне отношение к межэтническим бракам было самым разнообразным (из интервью с нашим респондентом Л. Салчак, в девичестве Шадриной, 2017 г.).

В Туве и в последующие годы создавались национально-смешанные семьи, хотя их число, начиная с 1970-х и до середины 1990-х годов, сократилось вдвое. По переписи 1989 г., на 1000 семей число национально-смешанных семей составило 86. Прирост смешанных семей за 1979-1989 гг. составил 0,9\% (Число и состав ..., 1991: 4). Конечно, это не большая прослой- 
ка, однако от характера формирования национально-смешанных семей, их самочувствия во многом зависело развитие таких важных процессов в тувинском обществе, как демографические, социальные, этнические, культурные.

Таблица 3. Число однонациональных и этнически смешанных семей по данным переписи населения 1979 и 1989 г2.

Table 3. Monoethnic and ethnically mixed households, from 1979 and 1989 census data

\begin{tabular}{|c|c|c|c|c|c|c|}
\hline \multirow{3}{*}{$\begin{array}{c}\text { По данным } \\
\text { переписей } \\
\text { населения }\end{array}$} & \multirow{2}{*}{\multicolumn{2}{|c|}{ Все семьи }} & \multicolumn{4}{|c|}{ в т. ч. семьи, где члены семьи принадлежат } \\
\hline & & & \multicolumn{2}{|c|}{ к одной национальности } & \multicolumn{2}{|c|}{$\begin{array}{c}\text { к разной } \\
\text { национальности }\end{array}$} \\
\hline & 1979 & 1989 & 1979 & 1989 & 1979 & 1989 \\
\hline \multicolumn{7}{|c|}{ Все население } \\
\hline Все семьи & 60382 & 70657 & 55757 & 64550 & 4625 & 6107 \\
\hline $\begin{array}{c}\text { в т. ч. семьи, } \\
\text { состоящие из: } \\
2 \text { чел. } \\
\end{array}$ & 12734 & 15128 & 11701 & 13732 & 1033 & 1396 \\
\hline 3 человек & 15261 & 15885 & 13861 & 14218 & 1400 & 1667 \\
\hline 4 человек & 13349 & 17012 & 12030 & 15300 & 1319 & 1712 \\
\hline $\begin{array}{c}5 \text { и более } \\
\text { человек }\end{array}$ & 19038 & 22632 & 18165 & 21300 & 873 & 1332 \\
\hline \multicolumn{7}{|c|}{ Городское население } \\
\hline Все семьи & 28221 & 35451 & 24941 & 30876 & 3280 & 4575 \\
\hline $\begin{array}{c}\text { в т. ч. семьи, } \\
\text { состоящие из: } \\
2 \text { чел. }\end{array}$ & 7293 & 9317 & 6551 & 8247 & 742 & 1070 \\
\hline 3 человек & 8865 & 9227 & 7809 & 7917 & 1056 & 1310 \\
\hline 4 человек & 7150 & 9462 & 6207 & 8132 & 943 & 1330 \\
\hline $\begin{array}{c}5 \text { и более } \\
\text { человек }\end{array}$ & 4913 & 7445 & 4374 & 6580 & 539 & 865 \\
\hline \multicolumn{7}{|c|}{ Сельская местность } \\
\hline Все семьи & 32161 & 35206 & 30816 & 33674 & 1345 & 1532 \\
\hline $\begin{array}{c}\text { в т. ч. семьи, } \\
\text { состоящие из: } \\
2 \text { чел. }\end{array}$ & 5441 & 5811 & 5150 & 5485 & 291 & 326 \\
\hline 3 человек & 6396 & 6658 & 6052 & 6301 & 344 & 357 \\
\hline 4 человек & 6199 & 7550 & 5823 & 7168 & 376 & 382 \\
\hline $\begin{array}{c}5 \text { и более } \\
\text { человек }\end{array}$ & 14125 & 15187 & 13791 & 14720 & 334 & 467 \\
\hline
\end{tabular}

(Женщина, семья, дети ..., 2001: 98).

Анализ статистических данных о численности семей Тувы по результатам переписей населения 1979 г. и 1989 г. позволяет сделать следующие выводы.

В 1970-1989 гг. отмечалось увеличение числа семей, однако преобладали однонациональные семьи, где все члены семьи состояли из одной национальности. По переписи 1989 г. их было 64,6 тысяч или 91,4\% к общему числу всех семей. Из них 36,9 тысячи семей $(61,3 \%)$ все члены семьи были тувинцы и 24,2 тысячи семей (37,5\%) все члены семьи русские. 
Перепись населения 1989 г. зафиксировала и увеличение в республике среднего размера тувинской семьи - 4,8 чел. Это было вызвано сохранением относительно высокой рождаемости у тувинцев. Что касается семей, где все члены семьи русские, то средний размер их уменьшился или существенно не изменился - 3,2 чел.

Переписью населения 1989 г. было учтено 6,1 тысячи смешанных семей (где все члены семей принадлежали к разным национальностям), что составило 6,8\% к общему числу всех семей против 7,7\% в 1979 г. (Женщина, семья, дети ..., 2001: 5). То есть роста не произошло.

\section{Отношение к межнациональным бракам в постсоветский период}

Начало 1990-х годов в Туве, как и в ряде российских регионах, было ознаменовано обострением межнациональных отношений (Москаленко, 2004: 179). Это оказало влияние на межэтнические установки и ориентации, а также на межэтнические браки.

В начале нулевых была отменена графа национальность в российском паспорте, поэтому нет точных статистических данных о браках между представителями конкретных национальностей, есть лишь сведения о браках с иностранцами, общая численность интернациональных браков.

С целью выяснить отношения окружающих к межнациональным бракам, в ходе анкетирования нами был задан вопрос тем, кто еще не был в браке «Готовы ли вы сами заключить брак с лицом другой национальности?» Ответы показали, что подавляющее большинство (70\%) опрошенных против этого и отдают предпочтение представителям своей нации $(78,3 \%)$ и не доверяют другой $(32,8 \%)$. При этом абсолютное большинство опрошенных респондентов, независимо от пола, возраста, образования и национальности, обращает внимание не на национальную принадлежность, а личные качества человека. Такое мнение высказали $74 \%$ русских и $70 \%$ тувинцев.

По мнению 54\% всех опрошенных, межнациональные браки как результат исторических и социально-культурных контактов народов, сближают народы, способствуют интернационализации культуры, быта, повседневной жизни.

По мнению тех, кто выступает за межнациональные браки, семья должна строиться на взаимопонимании и любви, а не на изживших себя предрассудках, ее благополучие и долголетие зависит только от ее членов. Так считают $70 \%$ тувинцев и $74 \%$ русских.

В то же время такие браки в отдельных случаях могут вызывать опасения за состояние национального самосознания народа. По мнению респондентов, «межнациональный брак способствует потере самобытности и национального своеобразия народа», «потере родного языка и национальной культуры».

Когда вопрос формулируется как просто отношение к межнациональному браку, то в ответах преобладает положительное отношение к таким бракам. Так считают чуть более половины тувинцев (54\%) и русских (57\%), что позволяет говорить о некоторой схожести мнений тувинцев и русских.

Но на конкретный вопрос: «Если ваш сын женится или дочь выйдет замуж за человека другой национальности, ваше отношение к этому?» - и тувинцы (46\%), и русские (43\%) ответили, что они против заключения их детьми межнациональных браков. К будущему своих детей в таком браке более лояльны женщины (61\%), нежели мужчины (48\%). Для женщин главный аргумент: «чтобы сын или дочь был(а) счастлив(а)». Мужчин больше волнует сохранение этничности своего народа. Более терпимо они относятся к межнациональному браку сына (46\%) с условием «лишь бы невестка была заботливой хозяйкой и хорошим человеком», и они не поддерживают межнациональный брак дочери (54\%).

То, что среди населения республики высок удельный вес противников создания национально-смешанных семей, во многом обусловлено распадом Советского Союза и последовав- 
шим обострением межнациональных отношений в 1990-е годы почти на всем постсоветском пространстве. По данным микропереписи населения 1994 г., доля этнически смешанных браков в Республике Тыва составила 6,2\% (Типы и состав ..., 1995: 76-77). Этот факт согласуется с ориентациями на национальность при выборе супруги (а) для всех респондентов в целом. Практически все младшие поколения в меньшей степени, чем старшие, ориентированы на этнически однородные браки (Гончарова, 2004: 221).

Негативную роль сыграли и разжигание межрелигиозной нетерпимости в регионах России, а также конфликты и столкновения скинхедов с представителями нерусских национальностей. Наш опрос показал, что большинство родителей (80\%) знают об агрессии скинхедов из Интернета, газет, телевидения. Обеспокоенные за безопасность своих детей, особенно обучающихся в учебных заведениях за пределами республики, они предпочитают видеть их избранников из представителей своего этноса. Это обусловлено и желанием сохранить этничность своего народа, сохранить национальную культуру.

«Религиозное возрождение» в постсоветский период привело к значительному росту интереса тувинцев, в первую очередь - тувинской интеллигенции, к традиционным верованиям своего народа, и соответственно, по мнению 43\% тувинцев, такие браки «не способствуют сохранению национальных обычаев, традиций и языка», для 35\% важным является «сохранение и развитие своей религии».

Мы можем назвать целый ряд причин, которые затрудняют жизнь супругов в межнациональных браках.

Например, религиозные причины. Есть буддийская традиция выбирать даты бракосочетания в зависимости от учета дат рождения новобрачных, традиция тувинцев иметь много детей (Кенин-Лопсан, 2006; Ламажаа, 2015: Электр. ресурс).

Наши наблюдения и беседы с людьми, состоящими в межнациональных браках, подтверждают, что чаще всего родители полагают, что «ребенок вырастет и выберет веру сам». Особенно если речь идет о родителях - представителях разных этнических культур и вероисповеданий. Однако, как показывает практика, чаще всего вопрос о выборе религии встает гораздо раньше, что неминуемо приводит к серьезным конфликтам в семье, иногда и к разводам, если супруги не сумеют найти ответ на этот и другие вопросы, связанные с разными обычаями и традициями русских и тувинцев.

Другая проблема в смешанных семьях - разные подходы к родственным связям и отношениям к расширенному кругу семьи. Если у тувинцев принято поддерживать широкие и крепкие связи с родственниками нескольких колен, в том числе в хозяйственном плане, то для русских это не характерно. Нуклеарная семья, например, мужа-тувинца и русской жены, может испытывать серьезные испытания в связи с этим, а также давления со стороны родственников, ожидающих от семьи соответствующего поведения, зачастую противоречивого из-за разницы традиций. Жена может быть недовольной чрезмерной, по ее мнению, заботой мужа о его родственниках, мужу может не хватать национальных праздников, которые они почти не отмечают, привычных блюд национальной кухни, которые ему не готовит супруга.

К проблемам относится и негативное отношение родных, которые вменяют смешанной семье в вину потерю этнической чистоты.

Еще одна проблема - самоидентификация детей, рожденных в межнациональных браках, которые в определенный момент вынуждены выбирать между национальностью отца или матери. Как показывают наблюдения, решающее значение в этом имеет преобладающая этническая среда. Так, дети от браков тувинских мужчин и русских женщин в пределах Тувы, где тувинцы составляют преобладающее большинство населения, чаще всего причисляют себя к тувинцам. Хотя в большинстве своем они считают себя русскими, потому что по принадлежности к культуре, ментальности, языку, особенностям характера, несомненно, русские. Отчасти осознанный выбор связан и с прагматическими целями: для поступления в вузы страны по национальным квотам, система которых была определена еще в советские времена. 
Численность молодежи Республика Тыва (от 14 до 30 лет) составляет 22,2\% населения (Итоги ..., 2012: 214), то есть почти четверть. Поэтому, интересно ее мнение по вопросам межэтнических браков, которые получила А. В. Седен в 2017-2018 гг. Она опросила студентов Тувинского государственного университета и Кызылского педагогического колледжа. Полученные ею ответы на вопрос «Как Вы относитесь к межнациональным бракам?» включали как положительное отношение к межнациональным бракам, так и отрицательное. То есть, отношение молодежи к межнациональным бракам во многом зависит от отношения к ним их родителей (Седен, 2018: 326). Кстати, по поводу отношения тувинской молодежи к таким бракам и ее приверженности к родительским установкам писала еще Г. С. Гончарова (Гончарова, 2004: 221).

По мнению большинства наших опрошенных (56\%), современное тувинское общество не одобряет межэтнические браки из-за их «непрочности», различия взглядов супругов на сам брак, на ведение домашнего хозяйства, из-за трудностей в общении с родственниками и различного отношения к традициям многодетности у тувинцев.

Тем не менее, исследования Г. С. Гончаровой показали, среди качественных характеристик семьи, которые люди считают очень важными, на первом месте стоят взаимопонимание супругов, взаимная поддержка, забота друг о друге. Затем следуют здоровье членов семьи и материальное благополучие семьи. Справедливое распределение обязанностей оценивается в меньшей степени, чем другие качественные характеристики семьи. При этом, доля считающих очень важными указанные характеристики среди русских в целом выше, чем среди тувинцев (85\% против 74\%). Наибольшие различия у тувинцев и русских по отношению к достатку в семье: тувинцы его ценят меньше (Гончарова, 2004: 218).

Таким образом, межэтнический брак не имеет однозначной оценки. В целом современная молодежь положительно относится к ним, чаще всего такой брак воспринимается ими как альтернатива однонациональному браку или как способ проявить свою самостоятельность. Вместе с тем, среди студенческой молодежи, как показало исследование А. В. Седен, немало тех, кто не одобряет межэтнические браки. Это во многом связано с тем, что в условиях трансформации российского общества недостаточным было внимание формированию позитивного образа межнациональных отношений, не говоря уже об интернациональном воспитании молодого поколения. К тому же, сказалось и обострение в 1990-е годы межнациональных отношений в республике, как и в некоторых других регионах страны. Все это привело к тому, что в массовом сознании межнациональные отношения, как и вопросы интернационального воспитания молодежи, утратили свою позитивную оценку.

\section{Заключение}

Подводя итоги, можно сказать, что исторические события XX века обусловили усиление в Туве межэтнических контактов, в том числе в форме семейных союзов между представителями разных национальностей. И это играло положительную роль для укрепления межэтнического согласия в обществе. В СССР активно проводилась политика дружбы народов, и пропагандировались межнациональные браки.

Образование смешанных семей влекло за собой качественно новые черты культуры, домашнего быта, традиций, отличающих их семейный уклад от семейного быта однонациональных семей, к которым ранее принадлежали супруги. Параллельно с этим в смешанных семьях происходили языковые процессы, межэтническое общение способствовало распространению двуязычия, а также широкому распространению родственных связей, отличающихся особой теплотой, солидарностью, взаимопомощью, обеспечивающих, в конечном счете, этнополитическую устойчивость многонационального региона.

В современной Туве также часто встречаются национально-смешанные семьи, однако общественное отношение к таким бракам резко изменилось. Отрицательное отношение к межнациональным бракам связано с религиозными различиями, разными традициями и 
обычаями. Из-за этого возникают между супругами разногласия, такие браки люди начинают расценивать как неустойчивые. Свою роль сыграло и усиление националистических тенденций в постсоветском обществе.

\section{СПИСОК ЛИТЕРАТУРЫ}

Анайбан, 3.В. (2011) Характеристика этнодемографических процессов Тувы в советский период [Электронный ресурс] // Новые исследования Тувы. № 2-3. URL: https://nit.tuva.asia/nit/article/ view/412 (дата обращения: 12.02.2019).

Базарова, А. Б., Дамба, Н. Ч. (2015) Воспитание детей на традициях и обычаях в межэтнических семьях (на примере русско-тувинских браков) // Актуальные проблемы исследования этноэкологических и этнокультурных традиций народов Саяно-Алтая. Материалы III международной научно-практической конференции молодых ученых, аспирантов и студентов, посвященной 20-летнему юбилею Тувинского государственного университета, Году народных традиций в Республике Тыва / отв. редактор У. В. Ондар. Кызыл : Изд-во ТувГУ. 325 с. С. 27-29.

Гончарова, Г. С. (2004) Семейно-брачные отношения у народов Сибири : проблемы, тенденции, перспективы. Новосибирск : Нонпарель. 286 с.

Городское население Тувинской АССР. Опыт социологического исследования (1981) / отв. ред. В. И. Бойко. Новосибирск : Наука. 224 с.

Доржу, 3. Ю. (2014) К вопросу об установлении протектората России над Тувой в 1914 г.// Власть. № 4. С. 157-161.

Доржу 3. Ю. (2015) Из истории столицы Республики Тыва - Кызыла // Вестник Бурятского научного центра Сибирского отделения Российской академии наук. № 1. С. 32-41.

Женщина, семья, дети (2001) / Федеральная служба государственной статистики. Территориальный орган Федеральной службы государственной статистики по Республике Тува. Кызыл: Тывастат. 98 с.

История Тувы (2001) : в 2 т. / под общ. ред. С. И. Вайнштейна, М. Х. Маннай-оола. Новосибирск : Наука. Т. I. 367 с.

Итоги переписи населения 1970 г. (1974): в 7 т. М. : Статистика. T.VII. 455 с.

Итоги Всероссийской переписи населения 2010 года (2013) : в 11 т. Кызыл : Территориальный орган Федеральной службы государственной статистики по Республике Тыва. Т. 4. Национальный состав и владение языками, гражданство населения Республики Тыва. 315 с.

Кенин-Лопсан, М. Б. (2006) Традиционная культура тувинцев / пер. с тув. А. А. Дугержаа, А. С. Дембиреля. Кызыл: Тувинское книжное издательство. 230 с.

Конституция (Основной закон) Союза Советских Социалистических Республик: принята на внеочередной седьмой сессии Верховного Совета СССР девятого созыва 7 октября 1977 г. (1977). М. : Известия. 79 с.

Конституция (Основной закон) Республики Тыва: принята всенародным голосованием 6 мая 2001 года. (2010). Кызыл : Центризбирком РТ. 81 с.

Кузьмин, Ю. В. (2000) Урянхай в системе русско-монголо-китайских отношений. Иркутск : Иркутский государственный университет. 65 с.

Ламажаа, Ч. К. (2015) Ребенок в тувинской культуре [Электронный ресурс] // Новые исследования Тувы. 2015, № 1. URL: https://nit.tuva.asia/nit/article/view/47 (дата обращения: 22.01.2019).

Монгуш, М.В. (2005) Тувинцы России, Монголии и Китая: этнические и этнокультурные процессы, современная идентичность : автореф. дис. ... д-ра. ист. наук. М. 50 с.

Москаленко, Н. П. (2004) Этнополитическая история Тувы в XX веке / отв. ред. С. И. Вайнштейн. М. : Наука. 222 с.

Народное хозяйство Тувинской АССР в девятой пятилетке (1976): статистический сборник. Кызыл : Тувинское книжное издательство. 240 с. 
Ойдуп, Т. М., Кылгыдай, А. Ч. (2012) Особенности межэтнических связей населения тувинскомонгольского приграничья // Социологические исследования. № 6. С. 136-140.

Российский статистический ежегодник. (2007). М. : Росстат. 826 с.

Советская Тува в цифрах (1991) : статистический сборник. Кызыл: Тывастат. 116 с.

Седен, А. В. (2018) Межэтнический брак в системе социально-ценностных ориентаций студенческой молодежи Республики Тыва // IV Центральноазиатские исторические чтения. Пространство культур: через призму единства и многообразия: сборник материалов Международной научно-практической конференции (г. Кызыл, 20-23 сентября 2018) / отв. ред. 3. Ю. Доржу. Кызыл : Изд-во ТувГУ. 350 с. С. 324-327.

Типы и состав домохозяйств в России (по данным микропереписи 1994 г.) (1995). М. : Госкостат России. 275 с.

Число и состав семей по Тувинской АССР по данным Всесоюзной переписи населения 1979 года (1982) / Статистическое управление Тувинской АССР. Кызыл : Тывастат. 17 с.

Число и состав семей по Тувинской АССР по данным Всесоюзной переписи населения 1989 года (1991) / Тувинское республиканское управление статистики. Кызыл: Тывастат. 13 с.

Дата поступления: 06.12.2018 г.

\section{REFERENCES}

Anaiban, Z. V. (2011) Kharakteristika etnodemograficheskikh protsessov Tuvy v sovetskii period [Ethno-demographic processes in Tuva during the Soviet period]. The New Research of Tuva, no. 2-3 [online] Available at: https://nit.tuva.asia/nit/article/view/412 (access date: 12.02.2019). (In Russ.).

Bazarova, A. B. and Damba, N. Ch. (2015) Vospitanie detei na traditsiiakh i obychaiakh v mezhetnicheskikh sem'iakh (na primere russko-tuvinskikh brakov) [Traditions and customs in bringing up children in interethnic families: the case of Russian-Tuvan marriages]. In: Aktual'nye problemy issledovaniia etnoekologicheskikh $i$ etnokul'turnykh traditsii narodov Saiano-Altaia [Urgent issues of research of ethno-ecological and ethno-cultural traditions of the peoples of Sayano-Altai] : Materials of the III international scientific and practical conference of young scientists, postgraduates and students dedicated to the 20th anniversary of the Tuva state University, the Year of folk traditions in the Republic of Tuva / ed. by U. V. Ondar. Kyzyl, TuvGU Publ. 325 p. Pp. 27-29. (In Russ.).

Goncharova, G. S. (2004) Semeino-brachnye otnosheniia u narodov Sibiri : problemy, tendentsii, perspektivy [Family and marriage relations among the peoples of Siberia : problems, trends, prospects]. Novosibirsk, Nonparel'. 286 p. (In Russ.).

Gorodskoe naselenie Tuvinskoi ASSR. Opyt sotsiologicheskogo issledovaniia [The urban population of the Tuva ASSR: A sociological study] (1981) / ed. by V. I. Boiko. Novosibirsk, Nauka. 224 p. (In Russ.).

Dorzhu, Z. Iu. (2014) K voprosu ob ustanovlenii protektorata Rossii nad Tuvoi v 1914 g. [On the establishment of the protectorate of Russia over Tuva in 1914]. Vlast', no. 4, pp. 157-161. (In Russ.).

Dorzhu Z. Iu. (2015) Iz istorii stolitsy Respubliki Tyva - Kyzyla [From the history of Kyzyl, the capital of the Republic of Tuva]. Vestnik Buriatskogo nauchnogo tsentra Sibirskogo otdeleniia Rossiiskoi akademii nauk, no. 1, pp. 32-41. (In Russ.).

Zhenshchina, sem'ia, deti [Woman, family, children] (2001). Kyzyl, Tyvastat. 98 p. (In Russ.).

Istoriia Tuvy [The History of Tuva] (2001) : in 2 vol. / ed. by S. I. Vainshtein and M. Kh. Mannai-oola. Novosibirsk, Nauka. Vol. I. 367 p. (In Russ.).

Itogi perepisi naseleniia $1970 \mathrm{~g}$. [The results of the 1970 population census] (1974): in 7 vol. Moscow, Statistika. Vol. VII. 455 p. (In Russ.).

Itogi Vserossiiskoi perepisi naseleniia 2010 goda [The results of the 2010 All-Russia population census] (2013) : in 11 vol. Kyzyl, Territorial'nyi organ Federal'noi sluzhby gosudarstvennoi statistiki po Respublike Tyva. Vol. 4 . Natsional'nyi sostav i vladenie iazykami, grazhdanstvo naseleniia Respubliki Tyva [Ethnic composition and language proficiency, citizenship of the population of the Republic of Tuva]. 315 p. (In Russ.). 
Kenin-Lopsan, M. B. (2006) Traditsionnaia kul'tura tuvintsev [Traditional culture of Tuvans] / transl. from Tuv. by A. A. Dugerzhaa and A. S. Dembirelia. Kyzyl, The Tuva book publishing house. 230 p. (In Russ.).

Konstitutsiia (Osnovnoi zakon) Soiuza Sovetskikh Sotsialisticheskikh Respublik [Constitution (Basic law) of the Union of Soviet Socialist Republics] : adopted at the extraordinary seventh session of the Supreme Soviet of the ninth convocation on October 7, 1977 (1977). Moscow, Izvestiia. 79 p. (In Russ.).

Konstitutsiia (Osnovnoi zakon) Respubliki Tyva [Constitution (Basic law) of the Republic of Tuva] : adopted by popular vote on 6 may 2001 (2010). Kyzyl, Tsentrizbirkom RT. 81 p. (In Russ.).

Kuz'min, Iu. V. (2000) Uriankhai v sisteme russko-mongolo-kitaiskikh otnoshenii [Uryankhai in the system of Russian-Mongolian-Chinese relations]. Irkutsk, Irkutskii gosudarstvennyi universitet. 65 p. (In Russ.).

Lamazhaa, Ch. K. (2015) Rebenok v tuvinskoi kul'ture [The child in Tuvan culture]. The New Research of Tuva, no. 1 [online] Available at: https://nit.tuva.asia/nit/article/view/47 (access date: 22.01.2019). (In Russ.).

Mongush, M. V. (2005) Tuvintsy Rossii, Mongolii i Kitaia: etnicheskie i etnokul'turnye protsessy, sovremennaia identichnost' [Tuvans in Russia, Mongolia and China: ethnic and ethno-cultural processes and contemporary identity]: Thesis of Dis.... Doctor of History. Moscow. 50 p. (In Russ.).

Moskalenko, N. P. (2004) Etnopoliticheskaia istoriia Tuvy $v$ XX veke [Ethnopolitical history of Tuva in the 20 th century] / ed. by S. I. Vainshtein. Moscow, Nauka. 222 p. (In Russ.).

Narodnoe khoziaistvo Tuvinskoi ASSR $v$ deviatoi piatiletke [The national economy of the Tuvan ASSR in the ninth five-year plan] (1976) : statistical collection. Kyzyl, The Tuva book publishing house. 240 p. (In Russ.).

Oidup, T. M. and Kylgydai, A. Ch. (2012) Osobennosti mezhetnicheskikh sviazei naseleniia tuvinskomongol'skogo prigranich'ia [Interethnic relations among the population of the Tuva-Mongolian borderlands.]. Sotsiologicheskie issledovaniia, no. 6, pp. 136-140. (In Russ.).

Rossiiskii statisticheskii ezhegodnik [Russian yearbook of statistics] (2007). Moscow, Rosstat. 826 p. (In Russ.).

Sovetskaia Tuva $v$ tsifrakh [Soviet Tuva in figures] (1991) : statistical collection. Kyzyl, Tyvastat. 116 p. (In Russ.).

Seden, A. V. (2018) Mezhetnicheskii brak v sisteme sotsial'no-tsennostnykh orientatsii studencheskoi molodezhi Respubliki Tyva [Interethnic marriage in the system of social and value orientations of students of the Republic of Tuva]. In: IV Tsentral'noaziatskie istoricheskie chteniia. Prostranstvo kul'tur: cherez prizmu edinstva i mnogoobraziia [IV Central Asian historical readings. Space of cultures: through the prism of unity and diversity] : proceedings of the International scientific and practical conference (Kyzyl, 20-23 September 2018) / ed. by Z. Iu. Dorzhu. Kyzyl, TuvGU Publ. 350 p. Pp. 324-327. (In Russ.).

Tipy i sostav domokhoziaistv $v$ Rossii (po dannym mikroperepisi 1994 g.) [Types and composition of households in Russia (according to the 1994 micro-census)] (1995). Moscow, Goskomstat Rossii. 275 p. (In Russ.).

Chislo i sostav semei po Tuvinskoi ASSR po dannym Vsesoiuznoi perepisi naseleniia 1979 goda [The number and composition of families in the Tuvan ASSR according to the all-Union population census of 1979] (1982). Kyzyl, Tyvastat. 17 p. (In Russ.).

Chislo i sostav semei po Tuvinskoi ASSR po dannym Vsesoiuznoi perepisi naseleniia 1989 goda [The number and composition of families in the Tuvan ASSR according to the all-Union census of 1989] (1991). Kyzyl, Tyvastat. 13 p. (In Russ.).

Submission date: 06.12.2018. 